\title{
Budget Management and Project Performance, A Case Study of Equity Agency Banking Project
}

\author{
Nsengiyumva Adolphe, Dr.Gitahi Njenga* \\ Mount Kenya University School of Business and Economics Kigali, Rwanda
}

*Corresponding Authors: Dr. Gitahi Njenga, Mount Kenya University School of Business and Economics Kigali, Rwanda

\begin{abstract}
This present study assessed the effects of budget management on project performance in Rwanda, a case of Equity Agency Banking project. More specifically the study sought to establish the influence of Fund allocation management, Budget execution management and Variance determination on project performance of Equity Agency Banking projects. The study variables were intervened by top Management Support ability and technological factors. The present research was grounded on agency theory, utility theory and uncertainty theory. Descriptive research design was adopted and allowed the researcher to consider many different aspects of the budget management and their influence on the performance thus helping to gain new insights and ideas. These inherent attributes in line with the descriptive research survey design created an indepth analytical approach to the study while exploring widely all the aspects that are in line with budget management and performance of agency banking project in Equity Bank Rwanda. The population of the study was250 Equity bank staff who were directly involved with agency banking from which a sample of 154 respondents were drawn using Yamane formula. Probability technique of stratified random sampling was used to allocate samples in Equity Bank. The study used questionnaires containing mainly closed ended questions for ease of analysis. Upon the collection of the data the researcher analyzed descriptive statistics with the help of the measures of central tendency especially the mean and mode as well as measure of dispersion (standard deviation and variance) to analyze the characteristics of study variables using the SPSS Version 23 tool. The study findings showed that the all the specific variables were statistically significant. The research thus recommends that Equity agency banking should carefully identify the risks that may occur over the life of the project, from conception to operation, and allocate those risks to the participants who are best able to manage them along fund, budget and variance management.
\end{abstract}

Key words: Budget Management, Budget execution management, Fund allocation management, Variance determination, Project Performance.

\section{INTRODUCTION}

\subsection{Background of the Study}

Budgeting and accounting are critical components that must interact to achieve the goals and objectives of an organization. Budget acts as financial management tool used to measure the actual and forecast against the budget throughout the planning process, it also assists in monitoring and controlling of current performance by providing early warning of deviations from the plans and analyses the anticipated versus actual results.Budget provide a basis for directing and evaluating the performance of banks. Modern budgeting is best placed when performance management is integrated with known financial outcomes which are frequently re-forecasted on budget and linked to the analysis of performance trends. This will ultimately help banks not lose their control and accountability mechanisms.

\subsection{Statement of the Problem}

Most banks fail to perfectly satisfy the requirements of budgeting as an overall performance measures which in most cases are a set of multidimensional measures. The banks performance has implications to its health and ultimately its survival. Equally, budgeting measures should allow for meaningful comparisons between expected and actual performance of agency banking in Equity Bank Rwanda but such is not the case as tohow effective the control measures are put in place.Agency banking projects fail despite substantial presence of budget management. This raises serious concerns as to how and if the planned budget is effective and adequate to success of project. The study thus sought to 
fill a scholarly gap with a contemporary significance, a methodological gap with means-end relationship to derive and ensure validity and completeness and a contextual gap showing the need, importance, urgency and necessity of the study. The current study therefore sought to bridge the gap between what has been previously studied by other researchers by undertaking a research on the effects of budget management and project performance in agent banking project of Equity bank Rwanda.

\subsection{Objectives of the Study}

$>$ To assess the influence of Fund allocation management on project performance of Equity Agency Banking projects

$>$ To examine the influence of Budget execution management on project performance of Equity Agency Banking projects

$>$ To analyse the effect of Variance determination on project performance of Equity Agency Banking projects

\subsection{Scope of the Study}

The research was undertaken at Equity Bank Rwanda on the Agency banking project for period three years from 2018 to 2020. The research analyzed the effects of budget management and project performance, examined budget management influence of project performance at Equity bank agency project; assessed budget management affect project performance at Equity bank agency project and established the relationship of budget management and project performance at Equity bank agency project.

\section{LITERATURE REVIEW}

\subsection{Theoretical Framework}

Several theories applicable to budget management and project success were outlined. These included the agency theory, the utility theory and the uncertainty theory.

\subsubsection{Project Performance}

This refer to the activities which needed the execution of project according to predefined plans which is within time, budget and specification Beck and Crane (2000). Projects achieve objectives through project management which have phases as per categorized by Pinto (2007); Conceptualization, Planning, Execution, and Termination. Initial goals and technical specifications must be developed for the project with scope, required resources, stakeholder's involvement through feasibility study and these set of activities take place during Conceptualization phase.

At the Planning phase the results of the conceptualization phase are further developed into comprehensive specifications, graphic, schedules and other plans. More activities such as development of objectives, breakdown of work packages, resources assigned and how the project will be completed elaborated as well as schedule, and estimated cost. Finally, the identification of stakeholders is made with communication plan describing information needs and how the information will be delivered to the stakeholders (Patel, 2008). Then comesto the Execution phase which is the real performance of the project. Progress is continuously monitored and appropriate adjustments are made and variances recorded so as to maintain the original project plan.

During project execution, project tasks have been carried out and progress information is being reported through regular team meetings. This information helps the project manager to compare results from the project performance with the plan and then take measures to correct. When the completed project is handed over to the client, Termination occurs at which documentations are provided to the firm, contracts with suppliers are terminated, the resources of the project are released and the stakeholders told of the termination. At close down lessons learnt are compiled and analyzed to provide insight for future management teams (Westland, 2006).

\subsubsection{Budget Management}

The budget was explained by Ax el. (2011), as revenue estimation and expense of specified future period of time ofan organization whichis reevaluated on period basic and Greve (2011) said that it a tool used by staff in order to achieve planed goals of the company and it is very important for the big 
company for taking decision making. He pointed also that the rule of budget as control will not be the same as the one used for planning. Kullvén (2009) defined the Budget management as way on managing and tracing income and expenses. The company's budget is composed by the departmental budgets and each manager is sole responsible for its budget.

Budget management involves developing and managing a budget that covers all expenses incurred and keeps the project sustainable over the long run. Bergschrund (2009), preparing a budget is one of the processes of budget management thataims to make certain an outline of project budget is developed, justified and ready for use in a cost-effective manner. All départements are required for regularly monitor actualactivity, planned, control of expenditureand ensure that it is in line with availablefunds,

\subsection{Conceptual Framework}

According to Kothari (2010) a conceptual framework is a diagrammatic representation of variables deemed important in a study. It represents the researcher's ideological position as far as the study variables are concerned. This is hypothesized model showing the variables under study as conceptualized by the researcher. It demonstrated by the arrows to show the relationships and interaction between the variables that is, dependent and independent variables. This shows that project performance relates to budget management.

\section{Independent variableDependent variable}

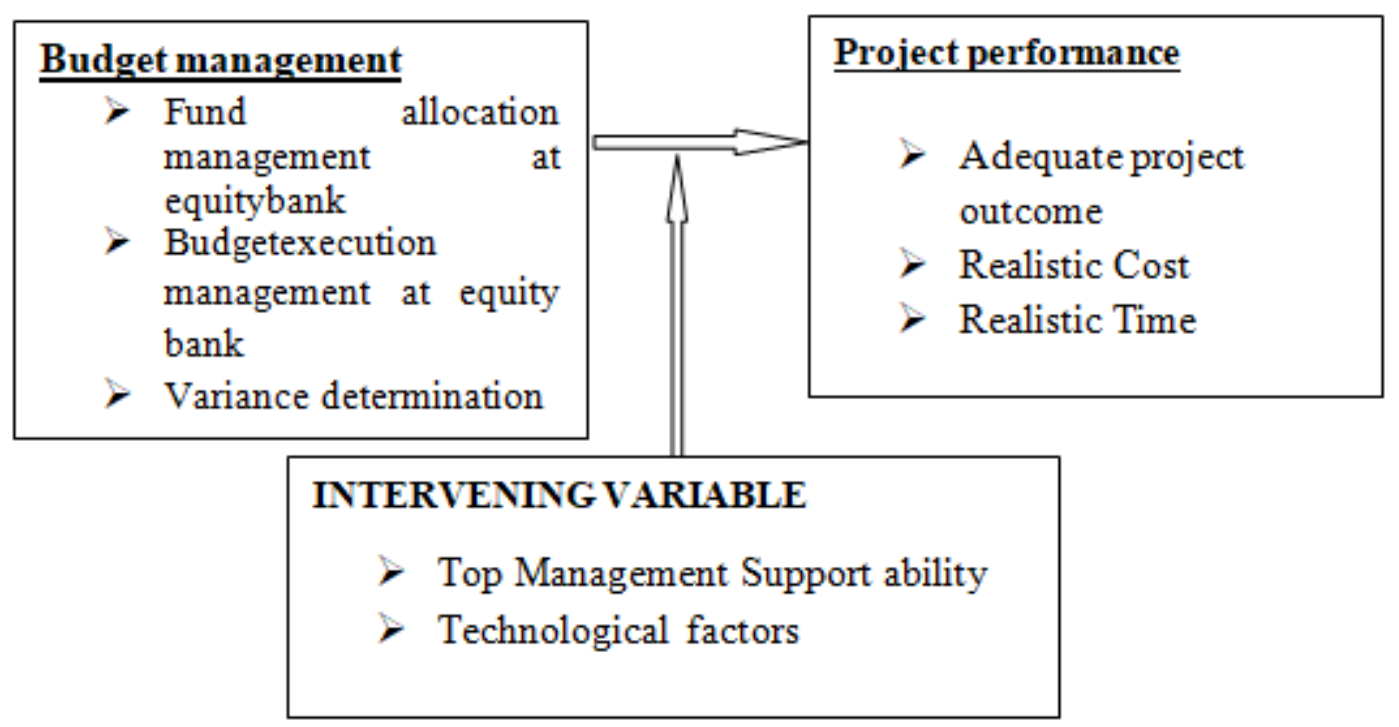

Source: Researcher2021

\section{RESEARCH METHODOLOGY}

\subsection{Research Design}

The researcher used descriptive as research design which is a type of description of population, situation or phenomenon that is being studied. This research design was an appropriate methodology to this study as the research explored extensively all the aspects that are in line with budget management and project performance.

\subsection{Target Population}

The target population is the total collection of elements in the current study to whom researcher makes inferences. Polit and Becks (2008) defines a population as all individuals or tangible things, which describe objects with mutual features. The population of research were the 153 agent staff and 97 agents of Equity bank, which deals with agent's project. The target population consisted of all the employees and heads of departments at Equity bank.

\subsection{Sampling Procedure and Sample Size}

Schindler and Cooper (2006), called sample as the individuals, objects and requirement having common features. Sample size determined as per the requested of representation level and this means 
that assurance is based on largest number sample. The respondents were selected as per stratified random technique. An important benefit of stratified random sampling is ensuring of presence to the key subgroup within the sample.

\subsection{Data Collection Instruments and Procedure}

The researcher used the questionnaires with opened and closed ended questions. The advantages of using the questionnaire as a data collection tool are that questionnaires are useful where a large amount of data needs to be; they are quick and economical. The questionnaires were administered face to face.

\subsection{Validity and Reliability of Research Instrument}

Before, actual research was done, the researcher made sure that the instrument was checked for validity and pre-tested to determine its reliability. Reliability refers to the consistency with which repeated measures produce the same results across time and across observers. Questionnaires were developed in line with the research objectives and questions. In addition, a pre testing of the questionnaires were conducted to guarantee common understanding of the questionnaires items among the respondents.

\subsection{Data Analysis Method}

The data examined was using descriptive statistics in frequency tables. To enable the researcher to gain ground for drawing conclusion, this exercise involved editing, tabulation, SPSS version 21, and interpretation of findings.Editing was used in order to detect errors and omission, correct them and certify that minimum data quality standards are achieved, the data collected was edited after getting the responses from respondents. The research used Tabulation for making statistic and evaluation of data accuracy and reliability rating respondents in terms of percentages. Tables were used for easy presentation and interpretation of data. Thedata was interpreted on the basis of percentages that were obtained to show the relationship among variables. This helped to identify the major direction of information that were gotten during the research. This research used descriptive statistics and Pearson Chi-Square to analyze the research objectives.

\section{RESUlts AND Discussions}

\subsection{Presentation of Findings}

\subsubsection{Influence of budget management on project performance of equity agency bank}

The results of the specific objective are depicted in the research finding.

Table1. Budget management and project performance

\begin{tabular}{|c|c|c|c|c|c|c|c|}
\hline Variable & 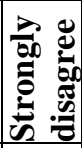 & 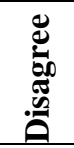 & 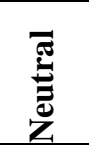 & 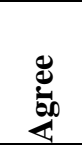 & 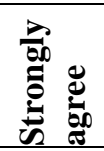 & Mean & $\begin{array}{l}\text { Std. } \\
\text { deviation }\end{array}$ \\
\hline & $\begin{array}{l}\mathbf{F} \\
\%\end{array}$ & $\begin{array}{l}\mathbf{F} \\
\%\end{array}$ & $\begin{array}{l}\mathbf{F} \\
\%\end{array}$ & $\begin{array}{l}\mathbf{F} \\
\%\end{array}$ & $\begin{array}{l}\mathbf{F} \\
\%\end{array}$ & & \\
\hline \multirow[t]{2}{*}{ Does project start and end with anticipated budget } & 15 & 3 & 16 & 53 & 63 & 3.973 & 1.2313 \\
\hline & 10 & 2 & 10.7 & 35.3 & 42 & & \\
\hline The budget of opening and & 14 & 4 & 14 & 45 & 73 & 4.06 & 1.23826 \\
\hline Operating agency are heap & 9.3 & 2.7 & 9.3 & 30 & 48.7 & & \\
\hline Costs establishing agent & 12 & 5 & 15 & 46 & 72 & 4.0733 & 1.19897 \\
\hline outlet is cheap & 8 & 3.3 & 10 & 30.7 & 48 & & \\
\hline The budget of your project facilitate the bank & 14 & 5 & 15 & 53 & 63 & 3.9733 & 1.22582 \\
\hline to deliver good service to & 9.3 & 3.3 & 10 & 35.3 & 42 & & \\
\hline \multicolumn{8}{|l|}{ the customer } \\
\hline Establishment cost end with achieving planned & 13 & 6 & 13 & 45 & 73 & 4.06 & 1.23283 \\
\hline goals. & 8.7 & 4 & 8.7 & 30 & 48.7 & & \\
\hline
\end{tabular}

\subsubsection{Relationship between fund allocation and project performance}

Chi-Square Tests and correlation used to find out the relationship between fund allocation and project performance in agency banking project. 
Budget Management and Project Performance, A Case Study of Equity Agency Banking Project

Table2. Chi-Square Tests between fund allocation and project performance

\begin{tabular}{|l|l|l|l|}
\hline & Value & df & Asymp. Sig. (2-sided) \\
\hline Pearson Chi-Square & 15.673 & 4 & .003 \\
\hline Likelihood Ratio & 16.161 & 4 & .003 \\
\hline Linear-by-Linear Association & 2.446 & 1 & .118 \\
\hline N of Valid Cases & 150 & & \\
\hline
\end{tabular}

The study indicates a statistically significant positive relationship between budget management in terms of fund allocation and project performance because the p-value of all the measures which is $\mathrm{p}=.003$ is not greater than value set of $\mathrm{p}<0.05$. It further shows that Tests for Pearson chi-squire on the respondents' mean scores for budget management and project performance revealed that both fund allocation and project performance had relationship. Thus, adopting Pearson chi-square was conducted using the means for budget management and project performance. As stated, our alpha is 0.05 , there is a relationship between the variables since with Alpha of 0.05 and asymp sig2.

\subsubsection{Effect of Budget Management on Agency Project Performance}

As per the findings of summary the staff of equity bank agent responded to the question raised by researcher on whether they agreed or not in order to determine relationship between budget and agency banking project performance at Equity bank in Rwanda.

Table3. Extent to which budget execution influence project performance

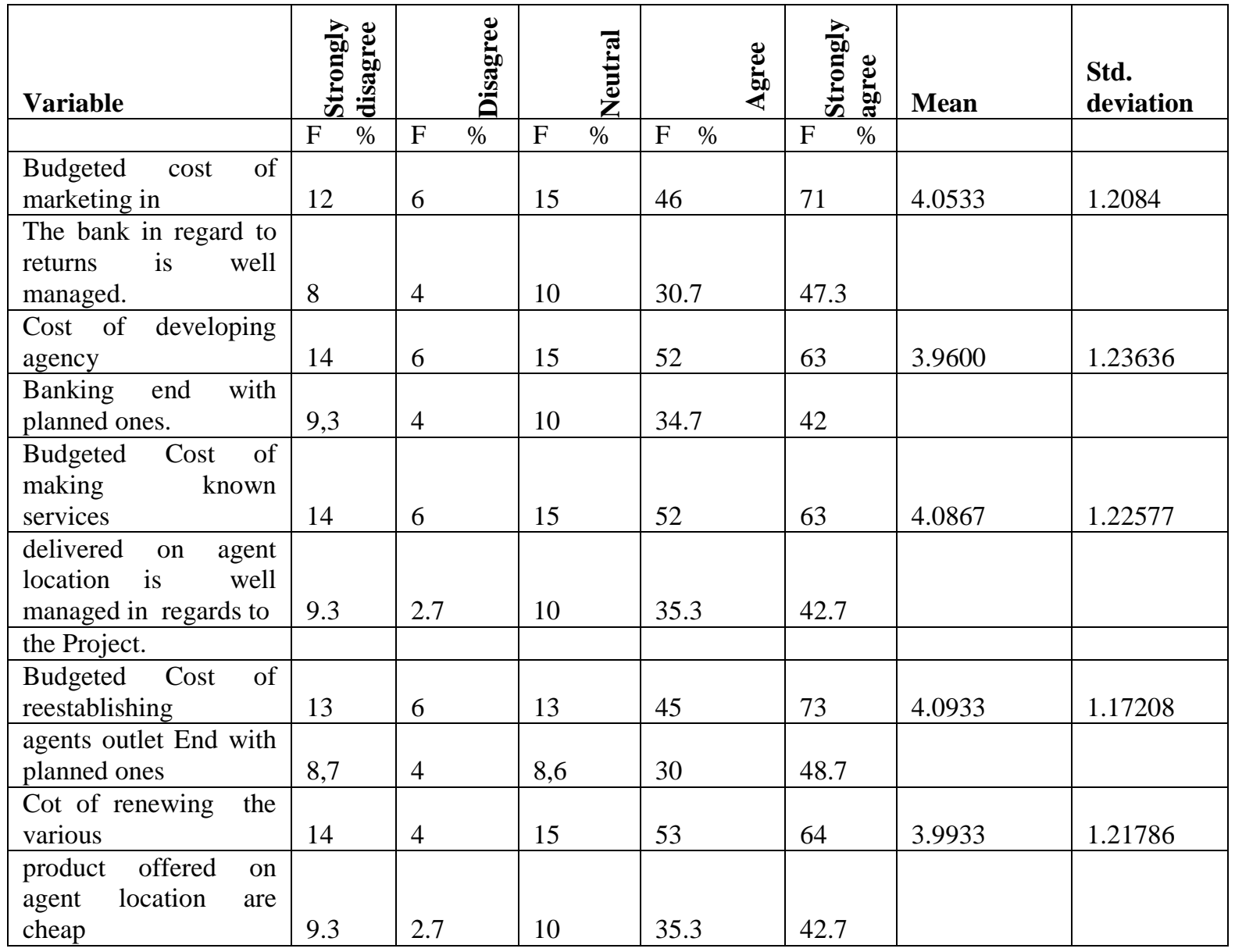

4.1.4. Relationship between budget management and project performance at equity bank agency project

The second objective of the study was to establish the relationship between budget management and project performance. The relationship between budget and project performance was analyzed using chi-squire and correlation as per below. 
Budget Management and Project Performance, A Case Study of Equity Agency Banking Project

Table4. Chi-Square Tests between budget management and project performance

\begin{tabular}{|l|l|l|l|}
\hline & Value & df & Asymp. Sig. (2-sided) \\
\hline Pearson Chi-Square & 31,245 & 12 & 0.002 \\
\hline Likelihood Ratio & 29.26 & 12 & 0.004 \\
\hline Linear-by-Linear Association & 1.31 & 1 & 0.252 \\
\hline N of Valid Cases & 150 & & \\
\hline
\end{tabular}

The means for budget and project performance were used to compute the Pearson chi square and determined the relationship between the two variables. The findings clearly show statistically significant relationship between budget execution and project performance $(p=.002$ which is less than $\mathrm{p}=0.05$ ). The association was positive, indicating that well managed of budgeted money was attributable to high levels of project success.

\subsubsection{Effects of budgeted costs of making awareness of agency banking project.}

Findings for the objective are discussed herewith.

Table5. Extent to which budgeted costs influence project performance

\begin{tabular}{|c|c|c|c|c|c|c|c|}
\hline Variable & 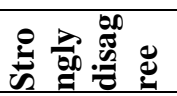 & 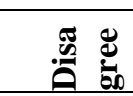 & 妾 & 娄 & 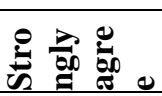 & Mean & $\begin{array}{l}\begin{array}{l}\text { Std. } \\
\text { deviation }\end{array} \\
\end{array}$ \\
\hline & $\mathrm{F} \%$ & F \% & F $\%$ & F $\%$ & $\mathrm{~F} \%$ & & \\
\hline $\begin{array}{l}\text { Availability of } \\
\text { resource } \\
\text { facilitated } \\
\text { Project to be }\end{array}$ & 13 & 5 & 15 & 52 & 64 & 4.0600 & 1.23283 \\
\hline $\begin{array}{l}\text { accomplished in } \\
\text { time }\end{array}$ & 9.3 & 3.3 & 10 & 34.7 & 42.7 & & \\
\hline $\begin{array}{l}\text { Project success } \\
\text { depends on well }\end{array}$ & 11 & 5 & 15 & 47 & 72 & 4.0933 & 1.17208 \\
\hline $\begin{array}{l}\text { usage of cost } \\
\text { planned for it. }\end{array}$ & 7,3 & 3,3 & 10 & 31.3 & 48 & & \\
\hline $\begin{array}{lr}\text { Does } & \text { your } \\
\text { project failed due }\end{array}$ & 48 & 5 & 15 & 52 & 64 & 3.9800 & 1.22868 \\
\hline $\begin{array}{l}\text { of wrong } \\
\text { budget } \\
\text { management }\end{array}$ & 9.3 & 3.3 & 10 & 34.7 & 42.7 & & \\
\hline $\begin{array}{l}\text { Does top } \\
\text { management } \\
\text { intervene in } \\
\text { cost budgeting }\end{array}$ & 13 & 4 & 14 & 46 & 73 & 4.0800 & 1.21246 \\
\hline for such project? & 8.7 & 2.7 & 9.3 & 30.7 & 48.7 & & \\
\hline $\begin{array}{l}\text { You project was } \\
\text { achieved due of } \\
\text { having good } \\
\text { management }\end{array}$ & 12 & 6 & 15 & 46 & 71 & 4.0533 & 1.2084 \\
\hline $\begin{array}{l}\text { regarding budget } \\
\text { usage. }\end{array}$ & 8 & 4 & 10 & 30.7 & 47.3 & & \\
\hline
\end{tabular}

\subsubsection{Relationship between Budgeted Cost and Project Performance}

Determining the relationship with budget and project inat equity bank agency project was the final objectives of this study. In this sub section, the respondents' views on budgeted costs and its relationship with agency project was analyzed by using chi-squire.

Table6. Chi-Square Tests between budgeted costs and project performance

\begin{tabular}{|l|l|l|l|}
\hline & Value & df & Asymp. Sig. (2-sided) \\
\hline Pearson Chi-Square & 15,673 & 4 & 0.003 \\
\hline Likelihood Ratio & 16,161 & 4 & 0.003 \\
\hline Linear-by-Linear Association & 2,446 & 1 & 0.118 \\
\hline N of Valid Cases & 150 & & \\
\hline
\end{tabular}

A test of chi-square revealed that the respondent's means scores on availability of budgeted cost had positive impact on project performance. Thus, means for budget and project performance research 
used Pearson chi-square for determining the whether there is significantly a correlation between budgeted costs and project performance. Pearson chi-squire analysis as shown in the table 4.6 statistical relationship between budget management and project performance was significantly also with $(\mathrm{P}=.003 ; \mathrm{p}<0.05)$. The relationship was positive and very strong; indicating that well usage of budget costs was attributable to improved project performance. Based to the findings from the respondents where they were asked if the Project success depends on well usage of costs planned, the majority replied that when budgeted cost are well used bring implications to high performance of agency banking.

\section{Conclusion Of The Study}

The study concluded that Equity Bank Rwanda ought to identify project costs, and utilize the finances at their disposal through involvement of budget participation; budget information and budget controls.

\subsection{Recommendations of the Study}

The research thus recommends that Equity agency banking should carefully identify the risks that may occur over the life of the project, from conception to operation, and allocate those risks to the participants who are best able to manage them along fund, budget and variance management. Bottomup approach in budgeting should be incorporated while sharing of detailed budget information with staff will aid in improving budgetary controls through enforcing institution guidelines.

\subsection{Suggestions for Further Studies}

The researcher used the single industry but recommends future researchers should use different industries like telecommunication companies in order to fill the gap. Possibilities of exaggerated results from self-reported data may also exist where secondary data is not available for further validation. To handle this limitation, future research should combine the views of managers, competitors and other relevant organization stakeholders.

\section{REFERENCES}

[1] Atkinson, R. (1999). Project management: cost, time and quality, two bestguesses and a phenomenon, it's time to accept other success criteria. International Journal of Project Management, 17(6), 337-342,

[2] Cooper, D.R., \& Schindler, P.M. (2006), Business Research Methods, $9{ }^{\text {th }}$ Edition, New Delhi: McGrawHill International Edition

[3] Kothari, C. R. (2010). Research Methodology and Techniques 2nd Revised Edition. Published by New Age International.

[4] Polit, M., \& Becks, R. (2008). How Management Information can Improve Strategic Decision Making. England: Marakon Associates.

[5] Yamane, T. (1967). Statistics: An Introductory Analysis, 2nd Ed., New York: Harper and Row;

Citation: Nsengiyumva Adolphe, Dr.Gitahi Njenga. "Budget Management and Project Performance, A Case Study of Equity Agency Banking Project" International Journal of Managerial Studies and Research (IJMSR), vol 9, no. 8, 2021, pp. 9-15. doi: https://doi.org/10.20431/2349-0349.0908002.

Copyright: (C) 2021 Authors. This is an open-access article distributed under the terms of the Creative Commons Attribution License, which permits unrestricted use, distribution, and reproduction in any medium, provided the original author and source are credited. 